\title{
Ranking of the Factors Causing Cost Overrun in Infrastructural Projects of UAE
}

\author{
Ahmed Salem Ahmed Marey Alhammadi ${ }^{1}$, Aftab Hameed Memon ${ }^{2 *}$ \\ ${ }^{1}$ Faculty of Business and Technology Management, \\ Universiti Tun Hussein Onn Malaysia (UTHM), Batu Pahat, Johor, 86400 Parit Raja, MALAYSIA \\ ${ }^{2}$ Department of Civil Engineering, \\ Quaid-e-Awam University of Engineering, Science and Technology, Nawabshah, PAKISTAN \\ *Corresponding Author
}

DOI: https://doi.org/10.30880/ijscet.2020.11.02.025

Received 30 July 2020; Accepted 30 August 2020; Available online 02 September 2020

\begin{abstract}
Achieving completion of the projects within stipulated cost is the fundamental requirement of any client involved in construction projects. Especially when the projects are funded by government with the revenue generated from public where it supposed to produce more development with less investment. Unfortunately, many of the construction projects fail in meeting this basic criteria globally including UAE. Hence, this study drew attention to the factors responsible for cost overrun in construction of infrastructure projects in UAE. Data was collected through structured questionnaire survey from practitioners representing the client, consultant and contractors firms involved in infrastructure projects of UAE. Investigation involved 27 common factors categorized in three groups as design \& planning related factors, management related factors and resource related factors. With the statistical analysis of 59 completed survey forms, it was revealed that lack of coordination at design phase, uncompleted design on the tender's time and frequent design changes are top 3 factors in design and planning group while in management group top 3 factors causing cost overrun are poor supervision and timely instruction from contractor, contractual claims (ex. extension of time with cost claims) and poor site management. Contractor's financial constraints, poor labour productivity and resource deficiency and shortage of technical personnel (skilled labour) are reported as major resource related factor causing cost overrun in infrastructural projects of UAE. The practitioner should work out for controlling these factors to complete the projects within the stipulated cost and avoid cost overrun.
\end{abstract}

Keywords: Cost overrun, construction industry, inhibiting factors, UAE

\section{Introduction}

Construction projects have been regarded as major contributor to economic development of any country by contributing in the Gross Domestic Product (GDP). Besides contributing to the GDP, the construction industry provides employment for a large number of people, both skilled and unskilled workers. In order to employ these workers and carry out operations, huge investments are involved in construction projects. Construction is particularly significant in the individual livelihood of a large part of the population because of infrastructure such as electricity, water supply and treatment, transportation, housing and others. Construction is considered as a risky business with too many uncertainties that management has to deal with (Enshassi, Al Swaity, \& Arain, 2016). The construction process is subjected to the influence of highly changing variables and unpredictable causes, such as resources availability, 
environmental conditions, financial problems, political conditions, poor productivity, and contractual relations. Cost, time and quality have their proven importance as the prime factors for project success.

Construction projects often fail to complete with the cost, time, and quality limitations (Nega, 2008). Among these problems, cost overrun is referred as the significant criteria and this problem is not unique to developed countries but is also experienced in most of the developing economies too (Kaliba, Muya, \& Mumba, 2009). Flyvbjerg, Holm, \& Buhl (2003) studied 258 transportation infrastructure projects consisting of 58 rail project, 33 fixed link (bridges and tunnels) and 167 road projects located in 20 nations of 5 continents, including both developed and developing nations. The geographical distribution of projects included 181 projects in Europe, 61 projects in North America and 16 projects in other regions of the world. The main findings of the study revealed that 9 out of 10 projects fall victim to cost escalation where average cost escalation is $28 \%$. It was also reported that this problem of cost escalation has not be been decreased over past 70 years while cost escalation is more pronounced in developing nations than in North America and Europe. In a recent study of Pakistan, Memon, Memon, Soomro, \& Rahman (2019) highlighted that until today, this problem of cost overrun is a serious concern of the stakeholders involved in construction industry. Rahman, Foo, Memon, \& Nagapan (2019) studying schedule and cost behaviour of Malaysian construction project summarized that overall cost behaviour in construction projects is very poor which needs serious attention.

In order to monitor the costs incurred in a construction project, it is paramount that the budgeted or estimated costs are compared to the actual costs incurred for various activities in the project. Furthermore, cost overruns need a comprehensive analysis for the costs once the project is completed (Allahaim \& Liu, 2015). Personnel involved in project management of UAE construction industry intends to mitigate cost overruns in construction projects through project governance (Cardenas et. al. 2017).Since construction projects have a significant effect on the economy, it is important that the costs incurred in undertaking such projects be monitored and controlled closely. Hence, it is essential that cost overrun issue must be addressed carefully. Thus, this research work is focusing on studying the problems causing cost overrun in construction projects of UAE.

\section{Review of Literature}

Construction cost overrun refers to additional cost required for completion of the projects as compared to contracted cost. It is very common to see the over run of the cost in most of the projects at global level. This is overrun is resulted from various factor occurring during project life cycle of the construction works. To avoid construction cost overrun, very first and most important step is to identify and understand the causative factors responsible for cost overrun (Memon, Rahman \& Azis, 2011). Numerous researchers have worked on underpinning those factors for long time. Okpala \& Aniekwu (1988) conducted a questionnaire survey amongst the professionals involved in construction projects and found that delays and cost overrun are major issues of construction project which are caused by several factors where the significant factors are shortage of materials, financing, and payments for completed works and poor contract management. Jackson (2002) investigated the causes of cost overrun in construction works of United Kingdom (UK) and found that design changes, design development factors, information availability, method of estimation adopted, performance of design team and project management are major factors which cause cost overrun. Frimpong, Oluwoye \& Crawford (2003) carried out a survey in investigating the factors of cost overrun in Ghana and found that top 10 factors of cost overrun are monthly payment difficulties, poor contract management, material procurement, inflation, contractor's financial difficulties, escalation of material prices, cash flow during construction, planning and scheduling deficiencies, bad weather and deficiencies in cost estimates prepared. Le-Hoai, Lee, \& Lee (2008) investigated 21 common causes of time and cost overrun in Vietnamese construction industry. Through conducting the survey among the practitioners handling large projects, it was found that poor site management and supervision, poor project management assistance, financial difficulties of owner, financial difficulties of contractor; design changes are top five severe factors occurring in the projects causing delay and cost overrun.

Iyer \& Jha (2005) reported that conflict among project stakeholders, lack of knowledge/competence, poor project specific attributes, lack of cooperation, hostile socio-economic and climatic conditions, delayed decision making, aggressive competition during tendering and short bid preparation time are major reasons of cost performance in Indian construction works. Haslinda, Xian, Norfarahayu, Hanafi, \& Fikri (2018) conducted a research work for studying project performance of high rise building projects in Penang, Malaysia and reported that the leading factors causing cost overrun are poor pre-construction budget and material cost planning, inaccurate quantity take-off and material cost increased due to inflation. On the other hand, Abdullah, Alaloul, Liew, \& Mohammed (2018) investigated the behaviour of cost performance in Palm oil Refinery project of Malaysia through questionnaire survey and revealed that delays in subcontractor's work, lack of sub contractors' skill and poor planning \& scheduling are critical factors of cost overrun. Babu \& Raju (2019) conducted a questionnaire survey amongst the major stakeholders involved in construction works and reported that that major factors of cost overrun in construction projects are inaccurate estimate, poor site management $\&$ supervision, ineffective planning \& scheduling of the contractors, improper construction methods implemented by the contractors, delay in sub-contractor's work and shortage of construction materials in market. Memon, Memon, Soomro, \& Rahman (2019) studied cost performance in construction works of Pakistan through questionnaire survey and found that all the stakeholders i.e. client, consultant and contractors agreed that common factors of cost overrun in construction works are lack of communication between parties, delay in obtaining 
the permits from governmental agencies, shortage of technical personnel (skilled labour), poor site management, lack of coordination between parties and poor financial control on site. Egila, Balogun, \& Yusuf (2020) conducted a survey in Nigeria to identify the factors of cost overrun. Through inferential statistics using Relative importance index (RII) test, the author identified factors as man related, money-related, machine-related, material related, environmentalrelated, and method related factors. Amongst those man and money related factors were reported as the highest factors, hence the research recommended that the Government should create an enabling environment, making suitable policy for the construction company to operate. Susanti (2020) evaluated the difference in perspectives between owner and contractor and found that most critical factor causing cost overrun by owner is "additional requirement" while contractor highlighted that "rework and delay in land acquisition" is a common issue which causes cost overrun. Besides that, both the owners and contractors agreed that another major factor of the cost overrun is inaccuracy in budgeting and resource planning. Through comprehensive review of literature a total of 27 common factors were identified and categorized in 3 groups as in Table 1.

Table 1 - Common factors causing cost overrun

\begin{tabular}{|c|c|}
\hline No & Description of factors causing cost overrun $(t)$ \\
\hline \multicolumn{2}{|r|}{ Design \& planning related factors } \\
\hline 1 & Construction's design errors \\
\hline 2 & Frequent design changes \\
\hline 3 & Uncompleted design on the tender's time \\
\hline 4 & Inadequate planning and scheduling \\
\hline 5 & Incomplete drawings and construction's documentations provided by contractor \\
\hline 6 & Lack of coordination at design phase \\
\hline 7 & Project scope variations \\
\hline \multicolumn{2}{|r|}{ Management related factors } \\
\hline 8 & Incompetent subcontractors \\
\hline 9 & Poor site management \\
\hline 10 & Poor supervision and timely instruction from contractor \\
\hline 11 & Poor site supervision \\
\hline 12 & Inaccurate and poor initial time and cost estimations \\
\hline 13 & Owner's payment delays \\
\hline 14 & Unsuitable leadership style of construction/project manager \\
\hline 15 & Imprecise quantity take-off \\
\hline 16 & Lack of coordination between designer and contractors \\
\hline 17 & Contractual claims (ex. extension of time with cost claims) \\
\hline 18 & Slowness of the owner's decision making process \\
\hline \multicolumn{2}{|r|}{ Resource related factors } \\
\hline 19 & Lack of experience \\
\hline 20 & Skills Shortage \\
\hline 21 & Poor labour productivity and resource deficiency \\
\hline 22 & Lack of skilled sub-contractors/labours and technical staffs \\
\hline 23 & Contractor's financial constraints \\
\hline 24 & Owner's financial constraints \\
\hline 25 & Shortage of technical personnel (skilled labour) \\
\hline 26 & High Material Costs \\
\hline 27 & Fluctuation of material's prices \\
\hline
\end{tabular}

\section{Methodology}

This paper involved data collection through structured questionnaire amongst the major stakeholders involved in construction projects i.e. clients, consultants and contractors. A total of 120 questionnaire forms were distributed as 40 forms amongst the representatives of each stakeholder respectively. The respondents were contracted through email and in person. As response of the survey, only 65 completed forms were collected back among which 6 forms were 
incomplete. Those were omitted and remaining 59 forms were used for analysis purpose. The respondents contributing in this data collection process were asked to indicate the significance level of each of the factor listed in the questionnaire in causing cost overrun with the help of measurement scale as 01 for not significant, 02 for slightly significant, 03 for moderately significant, 04 for very significance and 05 for extremely significant. Collected data through the questionnaire forms was punched in the software package SPSS for analysis. Frequency of the responses for each factor in accordance with the measurement scale was computed with SPSS (Adeyemi, Martin and Kasim, 2015). Based on the frequency values, Average Index (AI) values for each factor were calculated with Microsoft Excel application to rank the factors. AI values were calculated using following formula:

$$
A I=\frac{\sum_{1}^{5} a_{i} x_{i}}{N}
$$

Where,

$A I=$ Average index value

$a_{i}=$ Measurement scale where $i$ varies from 1 to 5

$x_{i}=$ Frequency for each measurement scale

$N=$ Total number of responses

\section{Data Analysis and Results}

Gathered data was analysed statistical to understand the perception of the respondents regarding the factors of the cost overrun and to draw the conclusion. Prior analysis of data, characteristics of the respondents were studied and presented in tabular forms as in Table 2.

Table 2 - Characteristics of the respondents

\begin{tabular}{|c|c|c|c|}
\hline Description & Frequency & Percent & Cumulative percent \\
\hline \multicolumn{4}{|c|}{ Organization } \\
\hline Consultant & 8 & 13.6 & 13.6 \\
\hline Contractor & 22 & 37.3 & 50.8 \\
\hline Client & 29 & 49.2 & 100.0 \\
\hline \multicolumn{4}{|c|}{ Qualification } \\
\hline Diploma & 1 & 1.7 & 1.7 \\
\hline Bachelor degree & 42 & 71.2 & 72.9 \\
\hline Postgraduate & 16 & 27.1 & 100.0 \\
\hline \multicolumn{4}{|c|}{ Working sector } \\
\hline Public (Governmental) & 35 & 59.3 & 59.3 \\
\hline Private & 24 & 40.7 & 100.0 \\
\hline \multicolumn{4}{|c|}{ Working experience } \\
\hline Less than 5 years & 14 & 23.7 & 23.7 \\
\hline 5 to 10 years & 29 & 49.2 & 72.9 \\
\hline 11 to 15 years & 9 & 15.3 & 88.1 \\
\hline More than 15 years & 7 & 11.9 & 100.0 \\
\hline
\end{tabular}

From Table 2, it is seen that majority of the respondents belong to client's organizations followed by contractors and only $13.6 \%$ of responses were collected from consultant's representative. Although, the number of the questionnaire forms distributed amongst all the stakeholders was same i.e. 40 to each category of stakeholders but most of the consultants did not participate in the survey. The respondents taking part in this survey have obtained technical level of education where majority of respondents with $71.2 \%$ have completed engineering degree while $27.1 \%$ of the respondents have attained post graduate level of education. Among these $59.3 \%$ of the respondents are working with public sector organizations while $40.7 \%$ are working private organizations. Among these, majority of the private organizations was represented by the contractors. These respondents are working for several years in their organizations where $49.2 \%$ of the respondents are working for more than 5 years followed $23.7 \%$ of the respondents having experience of less than 5 years. $15.3 \%$ of the respondents have experience of working for more than 11 years and $11.9 \%$ of the respondents are working in construction industry for more than 15 years. These characteristics reveal that the respondents are technical personnel and aware of the construction process and occurring problems. Hence, the 
data can be considered as valid for further analysis. Gathered data was then tested for internal consistency by conducting reliability test of questionnaire through computing Cronbach's alpha values for the data. SPSS software package was used to calculate Cronbach's alpha which can be interpreted by a rule of thumb is derived by George (2011) as illustrated in Table 3.

Table 3 - Criteria for assessing reliability

\begin{tabular}{lc}
\hline Cronbach's alpha & Internal consistency \\
\hline $0.9 \leq \alpha$ & Excellent \\
$0.8 \leq \alpha<0.9$ & Good \\
$0.7 \leq \alpha<0.8$ & Acceptable \\
$0.6 \leq \alpha<0.7$ & Questionable \\
$0.5 \leq \alpha<0.6$ & Poor \\
$\alpha<0.5$ & Unacceptable \\
\hline & Source: George, 2011
\end{tabular}

Cronbach's alpha for each group of factor and for over all data was computed with SPSS software package where it was found that Alpha value for design and planning factors is 0.875 while alpha value for management related factors is 0.892. Similarly Cronbach's alpha value for resource related factors is 0.901 and the same for overall factors is 0.957. From these results it is evident that minimum value of Cronbach's alpha for the data is 0.875 and maximum value is 0.957 . Based on the values as in table 2, it can be concluded that with alpha value higher than 9, overall data as well as individual category of factors i.e. resource related factors have excellent consistency level while design $\&$ planning and management group of factors have alpha value less than 9 and can be interpreted as good level of consistency. This confirms that the reliability level of the data is satisfactory for further analysis. Data for the factors was analysed with AI value and ranked accordingly to assess the significance level of each factors. Table 4 presents the AI value and ranking of the factors in design and planning group of factors.

Table 4 - Ranking of the factors in design \& planning group

\begin{tabular}{llccccccc}
\hline No & \multicolumn{1}{c}{ Factors } & NS & SS & MS & VS & ES & AI & Rank \\
\hline 1 & Lack of coordination at design phase & 1 & 9 & 11 & 25 & 13 & 3.68 & 1 \\
2 & Uncompleted design on the tender's time & 2 & 10 & 12 & 23 & 12 & 3.56 & 2 \\
3 & Frequent design changes & 3 & 10 & 8 & 30 & 8 & 3.51 & 3 \\
4 & Incomplete drawings and construction's & 1 & 12 & 14 & 23 & 9 & 3.46 & 4 \\
& documentations provided by contractor & & & & & & & \\
5 & Inadequate planning and scheduling & 0 & 12 & 19 & 19 & 9 & 3.42 & 5 \\
6 & Project scope variations & 2 & 16 & 11 & 18 & 12 & 3.37 & 6 \\
7 & Construction's design errors & 2 & 11 & 16 & 24 & 6 & 3.36 & 7 \\
\hline
\end{tabular}

Note: NS= Not Significant, SS= Slightly Significant, MS= Moderately Significant, VS= Very Significant,

ES= Extremely Significant

From Table 4, it is seen that lack of coordination at design phase is reported as the most significant factor and in paced at first rank. This is true that if there is no proper coordination at design stage, it causes changes and modifications in design at later stage which hinder the progress of the works as well as need additional time and cost to complete the works. As perceived by the respondents uncompleted Design on the tender's time is the second major factors of cost overrun. It is common practice in construction industry that design drawings provided in tender and working drawings are different sets of drawing. Normally, tender drawing are review carefully after tendering process is started and corrected if there is any mistake of discrepancy. In most cases, if the working designs differ from tender drawing, the contractors claim extra cost even some times additional time. "Frequent design changes" is reported as third major factor of cost overrun. It is directly correlated with lack of coordination. The factors related to management group of factors were also analysed with AI values and ranked as shown in Table 5.

Table 5 - Ranking of the factors in management group

\begin{tabular}{lllllllll}
\hline No & Factors & NS & SS & MS & VS & ES & AI & Rank \\
\hline
\end{tabular}




\begin{tabular}{|c|c|c|c|c|c|c|c|c|}
\hline 1 & $\begin{array}{l}\text { Poor supervision and timely instruction } \\
\text { from contractor }\end{array}$ & 2 & 3 & 17 & 27 & 10 & 3.68 & 1 \\
\hline 2 & $\begin{array}{l}\text { Contractual claims (ex. extension of } \\
\text { time with cost claims) }\end{array}$ & 3 & 7 & 14 & 19 & 16 & 3.64 & 2 \\
\hline 3 & Poor site management & 1 & 10 & 14 & 24 & 10 & 3.54 & 3 \\
\hline 4 & $\begin{array}{l}\text { Inaccurate and poor initial time and cost } \\
\text { estimations }\end{array}$ & 3 & 8 & 13 & 24 & 11 & 3.54 & 3 \\
\hline 5 & Poor site supervision & 0 & 13 & 14 & 25 & 7 & 3.44 & 4 \\
\hline 6 & $\begin{array}{l}\text { Unsuitable leadership style of } \\
\text { construction/project manager }\end{array}$ & 1 & 13 & 13 & 23 & 9 & 3.44 & 4 \\
\hline 7 & $\begin{array}{l}\text { Lack of coordination between designer } \\
\text { and contractors }\end{array}$ & 4 & 9 & 12 & 25 & 9 & 3.44 & 4 \\
\hline 8 & $\begin{array}{l}\text { Slowness of the owner's decision } \\
\text { making process }\end{array}$ & 6 & 9 & 9 & 23 & 12 & 3.44 & 4 \\
\hline 9 & Incompetent subcontractors & 1 & 13 & 16 & 20 & 9 & 3.39 & 5 \\
\hline 10 & Imprecise quantity take-off & 3 & 11 & 16 & 20 & 9 & 3.36 & 6 \\
\hline 11 & Owner's payment delays & 6 & 13 & 7 & 22 & 11 & 3.32 & 7 \\
\hline
\end{tabular}

Note: NS= Not Significant, SS= Slightly Significant, MS= Moderately Significant, VS= Very Significant, $\mathrm{ES}=$ Extremely Significant

Table 5 indicates that from management point of view the most significant factors faced in UAE infrastructural projects is poor supervision and timely instruction from contractor. One of the reasons for this might be the practice of dependency of the contractors on subcontractor. Contractual claims (ex. extension of time with cost claims) are reported as second major factor. This factor has direct relation with the factors related to design and planning. If the projects face poor coordination or frequent changes, it hinders the work of contractors. Some of the time, the change can cause rework of activities also which results in claims for additional time as well as cost. Third major factor causing cost overrun poor site management which play very important role in the success. Together with the management, one of the key elements which are necessary for projects is the availability of resources on right time. There are several resource related factors causing cost overrun and ranking of the factors is presented in Table 6 .

Table 6 - Ranking of the factors in resource group

\begin{tabular}{|c|c|c|c|c|c|c|c|c|}
\hline No & Factors & NS & SS & MS & VS & ES & AI & Rank \\
\hline 1 & Contractor's financial constraints & 0 & 8 & 13 & 30 & 8 & 3.64 & 1 \\
\hline 2 & $\begin{array}{l}\text { Poor labour productivity and resource } \\
\text { deficiency }\end{array}$ & 0 & 10 & 12 & 28 & 9 & 3.61 & 2 \\
\hline 3 & $\begin{array}{l}\text { Shortage of technical personnel (skilled } \\
\text { labour) }\end{array}$ & 1 & 12 & 8 & 26 & 12 & 3.61 & 2 \\
\hline 4 & High material costs & 1 & 12 & 8 & 28 & 10 & 3.58 & 3 \\
\hline 5 & Fluctuation of material's prices & 0 & 10 & 17 & 21 & 11 & 3.56 & 4 \\
\hline 6 & Skills shortage & 1 & 14 & 11 & 21 & 12 & 3.49 & 5 \\
\hline 7 & Lack of experience & 3 & 16 & 5 & 22 & 13 & 3.44 & 6 \\
\hline 8 & $\begin{array}{l}\text { Lack of skilled sub-contractors/labours } \\
\text { and technical staffs }\end{array}$ & 1 & 10 & 17 & 25 & 6 & 3.42 & 7 \\
\hline 9 & Owner's financial constraints & 5 & 12 & 11 & 21 & 10 & 3.32 & 8 \\
\hline
\end{tabular}

Note: NS= Not Significant, SS= Slightly Significant, MS= Moderately Significant, VS= Very Significant, $\mathrm{ES}=$ Extremely Significant

From Table 6 above, it is evident that "contractor's financial constraints" is the most significant resource related factor causing cost overrun. It is common practice that one contractor handles several projects simultaneously and for achieving the progress on each project they shuffle the finance. If on any of the projects the contractor fails in achieving the set target, it effects on billing and disturbs the financial situation. Consequently, the projects are disturbed. Similarly, "poor labour productivity and resource deficiency" is the second major factors. This is true because the labour is the fundamental resource which uses all other resource like material and machinery to achieve the target. If the productivity of the labour is not satisfactory, then it will hinder the progress. Subsequently, the project will be delayed and will require additional cost to complete. Shortage of technical personnel (skilled labour) is the third major factors. UAE engages a huge number of foreign workers (skilled as well as unskilled). Since during last few months 
due to several reasons including COVID19, the movement of the workers from one country to other has been disturbed which has affected on the availability of adequate number of labour.

\section{Conclusion}

This study investigated the factors causing cost overrun in infrastructural projects in UAE through questionnaire survey amongst the practitioners. From statistical analysis of the data collected it was realized that cost overrun is a serious issue in UAE infrastructural projects. There are several design \& planning, management and resource related factors which affect directly on project cost resulting in cost overrun. The results of the analysis of data showed that, from design and planning group of factors top three factors are lack of coordination at design phase, uncompleted design on the tender's time and frequent design changes. Looking at the factors related to management, it is reported that critical factors include poor supervision and timely instruction from contractor, contractual claims (ex. extension of time with cost claims) and poor site management. On the other hand, contractor's financial constraints, poor labour productivity and resource deficiency and shortage of technical personnel (skilled labour) are significant factors related to resource in causing cost overrun in infrastructural projects of UAE. These findings highlight the need of taking corrective and controlling actions to avoid the issue of cost overrun.

\section{Acknowledgement}

The authors would like to thank Universiti Tun Hussein Onn Malaysia and BP Renalcare Sdn Bhd for supporting this study. Also we are thankful to construction practitioners for providing comprehensive and important information and a lot of cooperation which made data collection easier.

\section{References}

Abdullah, M. S., Alaloul, W. S., Liew, M. S and Mohammed, B. S (2018). "Delays and Cost Overruns Causes During Construction of Palm Oil Refinery Projects", International Conference on the Built Environment and Engineering (IConBEE2018), held on October 29-30, 2018 in Hotel Jen Puteri Harbour, Iskandar Puteri, Johor Bahru, Malaysia

Adeyemi, A., Martin, D and Kasim, R (2015). "Improvement of existing buildings for sustainability as against maintenance and rebuild", Proceedings of the $25^{\text {th }}$ Intenational Business Information Management Association conference-Innovation Vision 2020: From Regional Development Sustainability to Global Economic Growth IBIMA, pp.3527-3537.

Allahaim, F. S and Liu, L (2015). "Causes of cost overruns on infrastructure projects in Saudi Arabia", International Journal of Collaborative Enterprise, Vol. 5, No. 1-2, pp. 32-57.

Babu, V. R and Raju, A. S (2019). "A study on cost and time overruns in construction projects", Universal Review, Vol. VIII, No. I, pp. 615-619

Cardenas, I. C., Voordijk, H and Dewulf, G (2017). "Beyond theory: Towards a probabilistic causation model to support project governance in infrastructure projects", International Journal of Project Management, Vol. 35, No. 3, pp. $432-450$

Egila, A. E., Balogun, O. A and Yusuf, S. O (2020). "Assessment of delay and cost-overrun in federal road construction project in Abuja”, Independent Journal of Management \& Production, Vol. 11, No. 4, pp. 1184-1200.

Enshassi, A., Al Swaity, E and Arain, F (2016), "Investigating common causes of burnout in the construction industry", International Journal of Construction Project Management, Vol. 8, No. 1, pp. 43

Flyvbjerg, B., Holm, M. K. S and Buhl, S. L (2003). "How common and how large are cost overruns in transport infrastructure projects?", Transport Reviews, Vol. 23, No. 1, 71-88

Frimpong, Y., Oluwoye, J., \& Crawford, L (2003). "Causes of delay and cost overruns in construction of groundwater projects in a developing countries; Ghana as a case study", International Journal of Project Management, Vol. 21, pp. 321-326

George, D. (2011). SPSS for windows step by step: A simple study guide and reference, 17.0 update, 10/e. Pearson Education India 
Haslinda, A. N., Xian, T. W., Norfarahayu, K., Hanafi, R. M., \& Fikri, H. M (2018). "Investigation on the factors influencing construction time and cost overrun for high-rise building projects in Penang", In Journal of Physics: Conference Series, Vol. 995, p.012043

Iyer, K. C and Jha, K. N (2005)' "Factors affecting cost performance: evidence from Indian construction projects", International journal of project management, Vol. 23, No. 4, pp. 283-295

Jackson, S. (2002, 2-4 September). Project cost overruns and risk management. Paper presented at the Greenwood, D. (Ed.) Proceedings of Association of Researchers in Construction Management 18th Annual ARCOM Conference, Newcastle

Kaliba, C., Muya, M and Mumba, K (2009). "Cost escalation and schedule delays in road construction projects in Zambia”, International Journal of Project Management, Vol. 27, pp. 522-531

Le-Hoai, L., Lee, Y. D., \& Lee, J. Y (2008). "Delay and Cost Overruns in Vietnam Large Construction Projects: A Comparison with Other Selected Countries”, KSCE Journal of Civil Engineering, Vol. 12, pp. 6, pp. 367-377

Memon, A. Q., Memon, A. H, Soomro, M. A. and Rahman, I. A (2019), “Common Factors Affecting Time and Cost Performance of Construction Projects in Pakistan”, In Pakistan Journal of Science, Special Issue, September 2019

Memon, A. H, Rahman, I.A., and Azis, A.A.A, (2011). "Preliminary Study on Causative Factors Leading to Construction Cost Overrun", International Journal of Sustainable Construction Engineering and Technology (IJSCET), Vol. 2, No. 1, pp. 57-71. ISSN: 2180-3242.

Nega, F (2008), "Causes and effects of cost overrun on public building construction projects in Ethiopia", Unpublished doctoral dissertation, Addis Ababa University, Ethiopia.

Okpala, D. C., \& Aniekwu, A. N (1988). "Causes of high costs of construction in Nigeria”, Journal of Construction Engineering and Management Accounting Research, Vol. 114, No. 2, pp. 233-244

Rahman, I. A, Foo, L. C., Memon, A. H and Nagapan, S (2019), "Schedule and Cost Behaviour in Construction Works of Malaysia", In Pakistan Journal of Science, Special Issue, September 2019

Susanti, R (2020). "Cost overrun and time delay of construction project in Indonesia", In Journal of Physics: Conference Series, Vol. 1444, No. 1, pp. 012050, IOP Publishing 